\title{
The influencing factors of citizen of Bandung preferences towards dental quack on constructing custom-made orthodontic appliances
}

\author{
Akhyar Dyni Zakyah*, Shekarwangi Rosabella H*, Nuzulul Hafizoh AZ*, \\ Avi Laviana, * Asty Samiaty S."* \\ *Department of Orthodontics Faculty of Dentistry Universitas Padjadjaran, Indonesia \\ **Department of Community Dentistry Faculty of Dentistry Universitas Padjadjaran, Indonesia
}

\begin{abstract}
Introduction: Braces often used in the treatment of malocclusion. However, in recent years malocclusion no longer becomes the reason for orthodontic treatment. Many people use it merely for a lifestyle purpose, and most of them got it from the dental quack. This study was aimed to understand the influencing factors of the citizen of Bandung preferences towards dental quack on constructing custommade orthodontic appliances. Methods: This study was a cross-sectional study with purposive sampling technique consisted of 30 samples. The inclusion criteria were subject wearing dental quack custommade orthodontic appliance; citizen of Bandung; and willing to participate in the study. Exclusion criteria were subject refused to participate in the study. Results: The study showed that most of the subject (73\%) were using the treatment for the teeth alignment, and only a few were using for the lifestyle purpose only. From all subjects wearing orthodontic appliance, $63 \%$ of them were chosen dental quack custommade orthodontic appliance due to the lower price, and $37 \%$ of the rest due to peer's suggestion who had it before. The combination of the low income with the needs of orthodontic treatment and inadequate information regarding orthodontic appliance such as dental braces affected the subjects preferences towards the dental quack custom-made orthodontic appliance. Overall, the socioeconomic environment is the most influencing factor of preference. Conclusion: A lower price was the most influencing factor of high preferences for the dental quack custom-made orthodontic appliance.
\end{abstract}

Keywords: Fixed orthodontic appliances treatment, dental braces, malocclusion, dental quack

\section{INTRODUCTION}

The ideal dental arrangement is needed to improve the oral cavity function and better appearance. A treatment chose to achieve this goal is the fixed orthodontic appliance. ${ }^{1}$ Malocclusion treatment with the fixed orthodontic appliance usually takes one to two years, or even more.
In the past, the treatment gave the unwanted social impression such as ugly and strange looks and nerdy stigma. Also, the cost of the fixed orthodontic appliance was expensive and can only be made and performed by orthodontists. ${ }^{3}$ These conditions make fixed orthodontic appliance considered as an expensive and exclusive treatment. ${ }^{4}$ 
Nowadays, malocclusion is not becoming the only reason for orthodontic treatment. Fixed orthodontic appliance use has become a symbol of the high society status, exemplified by many celebrities. ${ }^{2,5}$ This condition has created a style wave in the society. Some of the capable societies will visit the orthodontists to get fixed orthodontic appliance treatment, but for those who had no affordabilities and want to get a lower price, will go to the dental quack. ${ }^{5,7}$

Research on orthodontic treatment performed by unauthorized dental quack discovered that the people who go to the dental quacks instead of dentists were mostly teenagers and young adults. Peers, mass media, and internet play important roles in the decision making of fixed orthodontic appliance usage. ${ }^{5,7}$ These people were not only come from low socioeconomic backgrounds, some even having higher education and live in big cities with many orthodontists. This study was aimed to understand the influencing factors of the citizen of Bandung preferences towards dental quack on constructing custommade orthodontic appliances.

\section{METHODS}

TThis research was a cross-sectional research with a population was the citizen of Bandung used dental quack custom-made fixed orthodontic appliances. The sampling technique used is

\section{Respondent's gender}

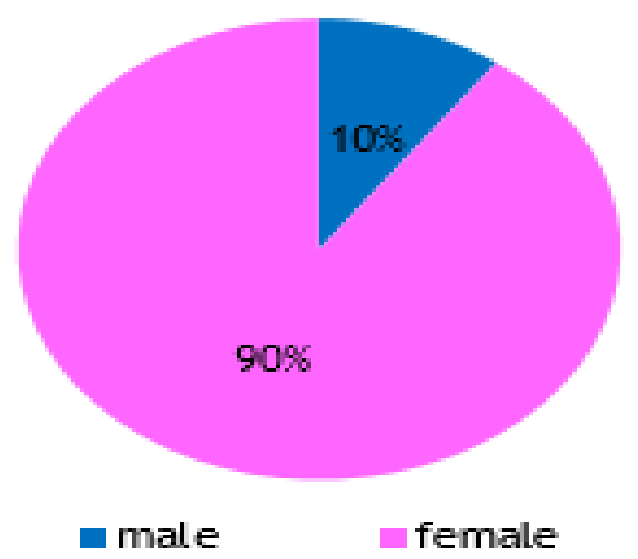

A accidental sampling. The sample of this study was the citizens met both inclusion and exclusion criteria. The inclusion criteria were subjects wearing dental quack custom-made orthodontic appliance; citizen of Bandung; and willing to participate in the study, with exclusion criteria were subjects refused to participate in the study. The total sample was 30 subjects. Questionnaires were given directly and indirectly (online survey) to the citizen of Bandung randomly.

\section{RESULTS}

From the total of 30 subjects, most respondent's were female (as much as 27 people, 90\%). Comparison of male and female respondent was 1: 9 . The age of respondents was ranged from 11 to 46 years old, with the average value was 21.10 years old (SD 6.04) and the most frequency was 20 years old. Characteristics of the sample based on gender and age were shown in Figure $1 \mathrm{a}$ and $1 \mathrm{~b}$.

The respondent's occupation (or respondent's parent's occupation, if the respondent was unemployed) were private employees (12 respondents); government employees (4 respondents); self-employed (8 respondents); and others (6 respondents). The respondent's income (or respondent's parent's income, if the respondent has no income) were categorized into less than Rp. 100,000 per month (2 people); Rp. 101,000 - Rp. 500,000 per month (1 respondent); Rp. 


\section{Occupation}

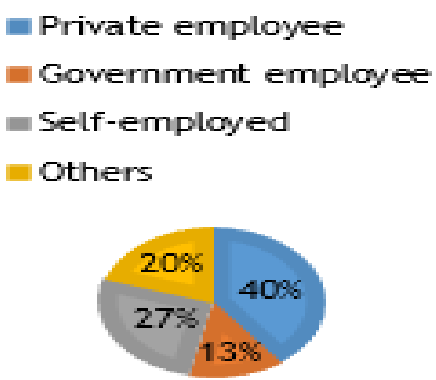

A

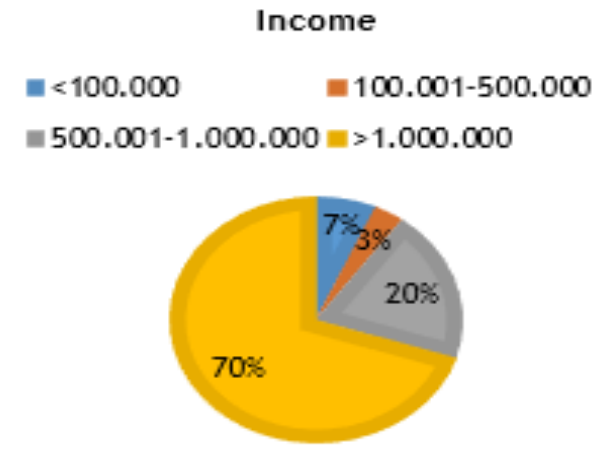

B

Figure 2a. Respondent's occupation; Figure 2b. Respondent's income

Control visit to dental quack

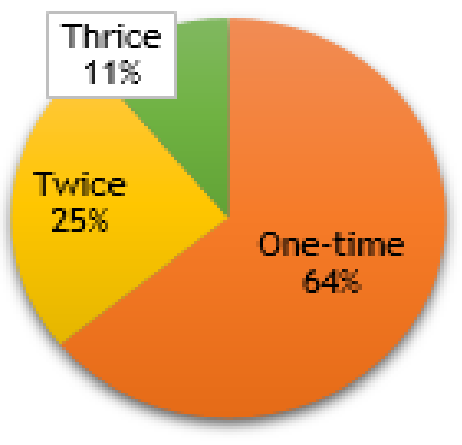

Figure 3a. Respondent's control visit frequency

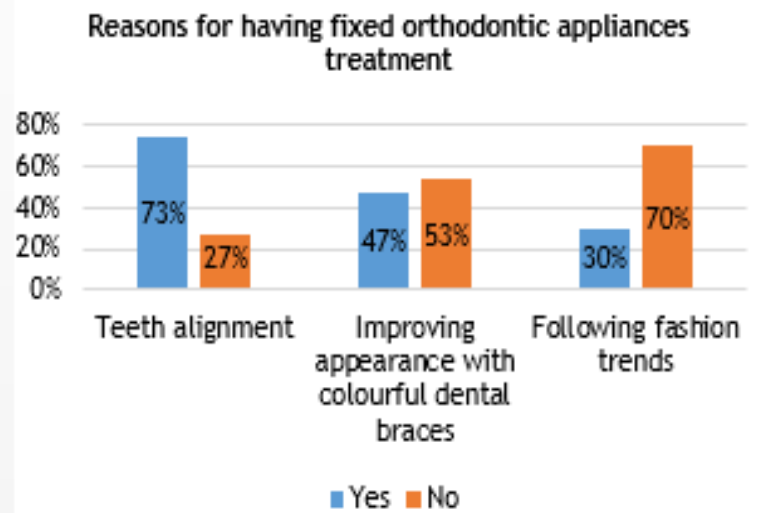

Figure 4a. Respondent's purposes for having fixed orthodontic appliances treatment

501,000 - Rp1,000,000 (6 respondents); and more than Rp. 1,000,000 per month (21 respondents). Characteristics of the sample based on occupation and income were presented in Figure $2 \mathrm{a}$ and $\mathbf{2 b}$.

During the treatment by the dental quack, all respondent was not doing the routine visit for the treatment control, only about 1-3 times after the orthodontic appliance installment.
Reason of having fixed orthodontic appliances treatment

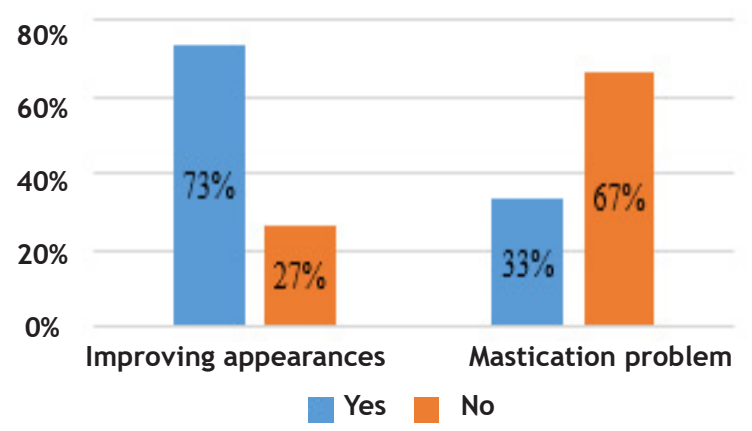

Figure 3b. Respondent's reasons for having fixed orthodontic appliances treatment

\section{Reasons for having fixed orthodontic} appliances treatment

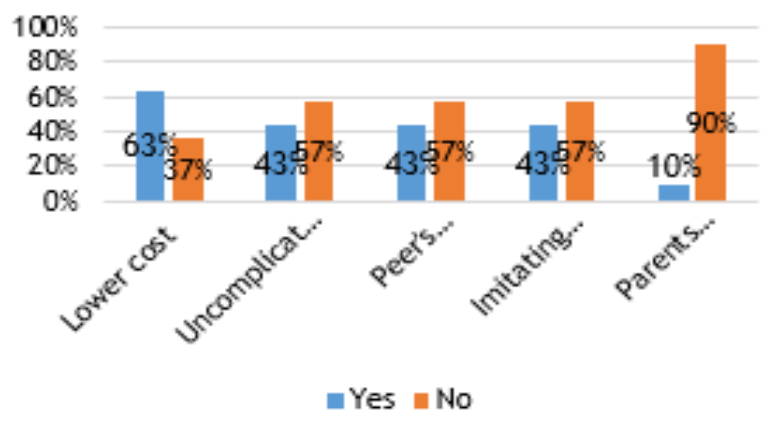

Figure 4b. Respondent's reasons for having fixed orthodontic appliances treatment

Respondent who's doing a-one-time control visit was as much as 13 respondents; twice was as much as 4 respondents; and thrice was as much as 13 respondents. Characteristics of the sample based on the frequency of control visit to the dental quack were presented in Figure 3a.

Malocclusion can cause many problems psychologically and physiologically. Individual 
reason for having a fixed orthodontic appliances treatment may include either or both of these factors. Respondent whose having fixed orthodontic appliances treatment for improving appearance was as much as 22 respondents; whilst due to the mastication problems were as much as 10 respondents. Respondent's reasons for having fixed orthodontic appliances treatment were shown in Figure $3 \mathrm{~b}$.

The fixed orthodontic appliances treatment was able to increase the user confidence by improving appearance and mastication ability and eliminate abnormalities caused by malocclusion. Respondent's purposes for having fixed orthodontic appliances included the teeth alignment (22 respondents); improving appearance with colourful dental braces (14 respondents); and following the fashion trends (9 respondents). The respondent's purposes for having fixed orthodontic appliances treatment was shown in Figure $4 a$.

Orthodontists should do the installation of the fixed orthodontic appliances. The respondent's reasons for having fixed orthodontic appliances included the low cost (19 respondents); uncomplicated procedures (13 respondents); peer's suggestion (13 respondents); imitating peers (13 respondents); and the parent's suggestion ( 3 respondents). The respondent's reasons for having fixed orthodontic appliances treatment was presented in Figure 4b.

\section{DISCUSSION}

The research conducted by Jung in 2010 showed the effect of malocclusion towards the decreased of confidence in women was more significant than men. ${ }^{9-11}$ This condition encouraged women more than men on having fixed orthodontics appliances treatment. ${ }^{9-13}$ In this study, the aesthetic factor on using fixed orthodontic appliances more likely encouraged women than men.

After puberty, malocclusions obviously seen due to the rapid growth of the maxillary, mandibular, and nasal bones that changes the face appearance. ${ }^{10,11}$ However, many people just realize the needs for orthodontic treatment in the young adulthood period (> 17 years)12 Dissatisfaction with their teeth condition increases with age. Therefore, the most age period of fixed orthodontic appliances users is the 17-25 years old period of age.

According to the Asian Development Bank $(\mathrm{ADB})$, middle-class people are people with an income range of Rp. 26,000 - Rp. 260,000 per day / Rp. 780,000 - Rp. 7,800,000 per month14. In this research, the subject's income level was mostly above Rp. 1,000,000 per month. This condition indicates that most of the subject was coming from the middle-class society. No presence of the subjects coming from the poor society showed that orthodontic treatment needs would be able to fulfilled for the middle-class society.

The research conducted by Bos in 2005 showed that the patient's obedience was influenced by the patient's satisfaction with the treatment. ${ }^{15}$ The research conducted by Utami in 2014 showed the patient's satisfaction level towards the dental quack was low, measured by the completeness and hygiene of the equipment used. ${ }^{5}$ Dissatisfaction of the dental quack's treatment was suspected of becoming the main reason for the patient's absence in the control treatment visit afterwards, only a few subjects came back to the dental quack for treatment control visit. Most of the subjects came once only for the installation of fixed orthodontic appliances and never came back for any control visit. This condition is prospering the fixed orthodontic appliances treatment by the dental quack because there is no information shared about any damage caused by the treatment.

The posterior region malocclusion will lead to adaptation and compensation mechanisms that arise along with changes occurred in the tooth alignment and inclination. The persistence of this type of malocclusion does not occur the mastication problem. This condition supported the fact that only a few subjects having fixed orthodontic appliances treatment due to the mastication problem. Besides, the improvement of the patient's body health was not significant because malocclusion did not cause pain. Longterm effects of successfully corrected malocclusion were not the patient's purpose for orthodontic treatment. 9,13,17

According to the study conducted by Jung in 2010, the anterior region malocclusion was the main cause of the fixed orthodontic appliances treatment. ${ }^{9}$ The main problem of 
the subject in this study was the aesthetic problem. This condition made the patient's appearance becoming unattractive decreasing the patient's confidence. Besides, the subjects entering pubertal age wanted the more attractive appearance to be socially acceptable in their peer's environment.9,12 Young adult subjects wanted malocclusion correction for professional reasons. ${ }^{17,18}$ All subjects wanted the better tooth alignment by using the fixed orthodontic appliances. The corrected anterior malocclusion was able to increase the patient's self-confidence to make the patient was more welcomed in their peer and working environment. ${ }^{12,17-19}$

The research conducted by Zahra in 2009 showed that all of the research subjects wanted to have a good tooth alignment but refused to have a fixed orthodontic appliances treatment due to the unattractive appearance of the appliances (dental braces). ${ }^{1,20}$ Study conducted by Rosvall et al. and Rivera et al. also resulted the same, but the study was done in Europe, and therefore, was less representing the characteristics of Indonesian people. Another research conducted at Jakarta in 2014 showed that the subject research was having a fixed orthodontic appliances treatment for aesthetical and lifestyle reason. ${ }^{5}$ In this research, however, discovered that in 3 years after, there was a decrease in the number of patients having a fixed orthodontic appliances treatment for the same reason. These patients were prioritizing more on the treatment results rather than the process.

According to the research conducted by Utami in 2014, the low cost of custom-made orthodontic appliances including the installment (below Rp.1,000,000) becoming the main reason for the patients having orthodontic treatment in the dental quack. ${ }^{5}$ Most of the research subject's income level was above Rp.1,000,000, and therefore, the treatment was becoming more affordable. Besides, the purpose of having orthodontic treatment will not be accomplished due to the absence of control treatment to the dental quack. Most of the people considered that by merely installing a fixed orthodontic appliance will fix the teeth alignment automatically, without any control treatment visit needed.The dentists should educate the people to fix this wrong paradigm.
The research conducted by Stephens discovered that information regarding dental health care mostly came from the dentists. ${ }^{21}$ Whilst in the rest of the research subjects that were rarely or never get any dental health care, the information came from the peer, mass media, family, and social media. ${ }^{9,19,21}$ However, this study showed that the influence of peers or family towards the preferences of orthodontic treatment were less significant. The influencing information was suspected to come from the social media. ${ }^{22}$

Bandung is one of the big city with the total population of 2.5 million people, with $40 \%$ amongst them are adolescents and young adults whom becoming the main focus of this research. The average level in Bandung is high school-educated, with the most occupation is in the private sector. With the low poverty level (about 5\%), Bandung is the city with high population of middleclass society. ${ }^{23}$ This socioeconomic condition is becoming the reason for a high demand for the custom-made fixed orthodontic appliances from the dental quack.

\section{CONCLUSION}

A lower price was the most influencing factor of high preferences for the dental quack custommade orthodontic appliance.

\section{REFERENCES}

1. Rosvall MD, Fields HW, Ziuchkovski J, Rosenstiel SF, Johnston WM. Attractiveness, acceptability, and value of orthodontic appliances. Am J Orthod Dentofacial Orthop. Mar 2009;135(3):276-7. DOI: 10.1016/j. ajodo.2008.09.020.

2. Malik S. Deadly Fashion Braces Are Big in Thailand. Vice [serial on internet]. Apr 12, 2012; [cited Sep 26, 2016]. Available from: https:// www.vice.com/en_us/article/nn47z8/ deadly-fashion-braces-are-big-in-thailand.

3. Feu D, Catharino F, Duplat CB, Capelli Junior J. Esthetic perception and economic value of orthodontic appliances by lay Brazilian adults. Dental Press J Orthod. 2012 SeptOct;17(5):102-14. DOI: 10.1590/S217694512012000500015.

4. Zahra IF. Rasa Percaya Diri pada Pasien 
Pemasang Kawat Gigi [minor thesis]. Palembang: Universitas Bina Darma; 2003.

5. Utami LA. Faktor-Faktor yang Berhubungan dengan Kepuasan Pengguna Pekerjaan Ortodonti Cekat oleh Tukang Gigi dari Perspektif Masyarakat [minor thesis]. Jakarta: Universitas Indonesia; 2014.

6. Anderson C, Kilduff GJ. The Pursuit of Status in Social Groups. Curr Directions Psychol Sci. 2009;18:295-8.

7. Rahmawati RA. Pergeseran Nilai dan Fungsi Behel Sebagai Simbol Status. [minor thesis]. Jakarta: Universitas Indonesia; 2013.

8. Pratiwi H. Fenomena Penggunaan Behel Gigi pada Kalangan Remaja. Komunitas. Mar 2016;5(1):1-15.

9. Jung MH. Evaluation of the effects of malocclusion and orthodontic treatment on self-esteem in an adolescent population. Am J Orthod Dentofacial Orthop. Aug 2010;138(2):160-6. DOI: $\quad 10.1016 / j$. ajodo.2008.08.040.

10. Wedrychowska-Szulc B, Syryńska M. Patient and parent motivation for orthodontic treatment-a questionnaire study. Eur J Orthod. Aug 2010;32(4): 447-52. DOI: 10.1093/ ejo/cjp131.

11. Kerosuo H, Abdulkarim E, Kerosuo E. Subjective need and orthodontic treatment experience in a Middle East country providing free orthodontic services: a questionnaire survey. Angle Orthod. Dec 2002;72(6):565-70. DOI:10.1043/0003-3219(2002)072<0565:SNAO $\mathrm{TE}>2.0 . \mathrm{CO} ; 2$.

12. Hamdan AM. The relationship between patient, parent and clinician perceived need and normative orthodontic treatment need. Eur J Orthod. Jun 2004;26(3):265-71.

13. Bos A, Hoogstraten J, Prahl-Andersen B. Expectations of treatment and satisfaction with dentofacial appearance in orthodontic patients. Am J Orthod Dentofacial Orthop. Feb 2003;123(2):127-32. DOI: 10.1067/ mod.2003.84.

14. Asian Development Bank. Key Indicators for Asia and the Pacific 2010, 41st ed; Special Chapter: The Rise of Asia's Middle Class. Mandaluyong City: Asian Development Bank
Cataloging-In-Publication Data; 2010. p. 4-19.

15. Bos A, Vosselman N, Hoogstraten J, PrahlAndersen B. Patient compliance: a determinant of patient satisfaction. Angle Orthod. Jul 2005;75(4):526-31. DOI:10.1043/00033219(2005)75[526:PCADOP]2.0.CO;2.

16. Cutroneo G, Vermiglio G, Centofanti A, Rizzo G, Runci M, Favaloro A, et al. Morphofunctional compensation of masseter muscles in unilateral posterior crossbite patients. Eur J Histochem. Apr 11, 2016;60(2):2605. DOI: 10.4081/ejh.2016.2605.

17. Marques LS, Pordeus IA, Ramos-Jorge ML, Filogônio CA, Filogônio CB, Pereira LJ, et al. Factors associated with the desire for orthodontic treatment among Brazilian adolescents and their parents. BMC Oral Health. Dec 18, 2009;9:34. DOI: 10.1186/14726831-9-34.

18. Jung $\mathrm{MH}$, Heo W, Baek SH. Effects of malocclusion on the self esteem of female university students. Korean J Orthod. Dec 2008;38(6):388-96. DOI: 10.4041/ kjod.2008.38.6.388.

19. Laakshmi GM. Reasons for seeking orthodontic treatment among south indian population-a questionnaire study. J Pharm Sci \& Res. 2016;8(7): p. 692-5.

20. Rivera SM, Hatch JP, Rugh JD. Psychosocial factors associated with orthodontic and orthognathic surgical treatment. Semin Orthod. 2000;6(4): p. 259-69. DOI: 10.1053/ sodo.2000.19704.

21. Stephens R, Ryan FS, Cunningham SJ. Information-seeking behavior of adolescent orthodontic patients. Am J Orthod Dentofacial Orthop. Mar 2013;143(3):303-9. DOI: 10.1016/j.ajodo.2012.10.018.

22. Al-Silwadi FM, Gill DS, Petrie A, Cunningham SJ. Effect of social media in improving knowledge among patients having fixed appliance orthodontic treatment: A singlecenter randomized controlled trial. Am J Orthod Dentofacial Orthop. Aug 2015;148(2): p. 231-7. DOI: 10.1016/j.ajodo.2015.03.029.

23. Statistics of Bandung City. Bandung City in Figures 2016. Bandung: BPS-Statistics of Bandung City; 2016. 